\title{
Editorial: Sea Level Variability and Change
}

\author{
Ivan D. Haigh ${ }^{1 *}$, Marta Marcos ${ }^{2}$, Sönke Dangendorf ${ }^{3}$ and Francisco Mir Calafat ${ }^{4}$ \\ ${ }^{1}$ Ocean and Earth Sciences, National Oceanography Centre, University of Southampton, Southampton, UK, ${ }^{2}$ Mediterranean \\ Institute for Advanced Studies (CSIC), Esporles, Spain, ${ }^{3}$ Department of Civil Engineering, Research Institute for Water and \\ Environment, University of Siegen, Siegen, Germany, ${ }^{4}$ National Oceanography Centre, Liverpool, UK
}

Keywords: sea level, coastal flooding, extreme events, tides, storm, storm surges, mean sea level

\section{Editorial on the Research Topic}

\section{Sea Level Variability and Change}

There is strong observational evidence that global mean sea levels are rising and there is great concern that the rate of rise will accelerate throughout the twenty-first century and beyond, significantly threatening coastal communities (Church et al., 2013; IPCC, 2014). With rapid population growth and accompanying infrastructure development at the coast, modern society has become increasingly vulnerable to even small changes in sea level. More than 600 million people currently live in coastal areas with an elevation less than $10 \mathrm{~m}$ above present-day mean sea level (McGranahan et al., 2007). An assessment of 136 of the world's largest port cities estimated that, by the 2070s, the population exposed to flooding risk may grow by more than a factor of three in these cities due to the combined effects of sea level rise, land subsidence, population growth, and urbanization, with asset exposure increasing to more than 10 times that of current levels (Hallegatte

\section{OPEN ACCESS}

Edited and reviewed by: Isabel Iglesias,

Interdisciplinary Centre of Marine and Environmental Research, Portugal

*Correspondence: Ivan D. Haigh i.d.haigh@soton.ac.uk

Specialty section:

This article was submitted to Coastal Ocean Processes, a section of the journal Frontiers in Marine Science

Received: 14 December 2016 Accepted: 09 February 2017 Published: 22 February 2017

Citation:

Haigh ID, Marcos M, Dangendorf S and Mir Calafat F (2017) Editorial: Sea Level Variability and Change. Front. Mar. Sci. 4:46. doi: 10.3389/fmars.2017.00046 et al., 2013). Therefore, understanding future sea level rise and variability is an urgent issue of utmost importance.

The 12 articles in this Research Topic assess sea level change and variability on a range of different temporal (from minute to hundreds of years) and spatial (individual beach to global) scales.

The first contribution to this Research Topic considers tides, which dominate sea level variability in a large proportion of the world's oceans. In a perspective article, Medvedev et al. evaluate the nature of tides in three enclosed basins, namely the Baltic, Black, and Caspian seas. Oceanic tides penetrate only weakly, or not at all, into these enclosed basins and consequently direct forcing of tides dominates the variability. The authors use spectral analysis on long observation time series and find that the formation and predominance of diurnal or semidiurnal tides in these seas appears to depend on the frequency-selective properties of the respective basins.

The next four contributions deal with meteorological influences on sea level. Vilibić et al. focus on meteotsunamis, which are atmospherically generated long ocean waves in the tsunami frequency band. Understanding of meteotsunamis has advanced considerably during the last two decades and the authors identify key research gaps and discuss different approaches for developing meteotsunami warning systems. Pérez-Gómez et al. analyse the characteristics of two high frequency sea level events recorded in European Atlantic waters, using sea level, wave, atmospheric pressure and wind datasets. The first event was associated with possible wave-induced "seiches" that occurred along the North coast of Spain during the storms of January/February 2014 and the second was a series of small sea level oscillations detected after an earthquake in the mid-Atlantic in February 2015. They consider these events in regard to the limitations of automatic 
algorithms for tsunami warning. Wadey et al. undertake a detail comparison of two key North Sea coastal flooding events that have occurred in the last 60 years. These events are the "Big Flood" of 31 January-1 February 1953 and the recent 5-6 December 2013 event. Using a range of oceanographic and meteorological datasets they: contrast the meteorological forcing; compare the high sea levels observed during both events; compare the coastal flooding and impact; and discuss the role of the improved flood defenses and storm surge forecasting since 1953. Using a set of 220 tide gauges, Mawdsley and Haigh investigate the temporal variations in storm surges around the world and the spatial coherence of its variability. They compare results derived from two parameters used to represent storm surge (skew surge and the more traditional, non-tidal residual) and compare inter-annual and multi-decadal variations in skew surge with fluctuations in regional climate indices. They find that using skew surge time-series improves estimation of long-term trends in storm surges, because phase offsets caused by time errors are not present in skew surge time-series.

Three contributions deal with longer-term changes in mean sea level. Hünicke and Zorita analyse mean sea level records in the Baltic and parts of the North Sea with the aim of detecting an acceleration of sea-level rise over the twentieth and twentyfirst centuries associated with climate change. Comparing a range of statistical methods they find positive, but not statistically significant, acceleration in the Baltic Sea area since 1900. They highlight that the failure to detect a significant acceleration in sea level could be due to the still small magnitude of the acceleration paired with high inter-annual sea-level variability at the regional scale, rather than the absence of acceleration linked to climate change. Andersen and Piccioni present an updated and improved version of the Danish Technical University's Arctic Ocean altimetric sea level time-series and use it to assess trends in mean sea level in this region. They find a total sea level rise of $2.2 \pm 1.1 \mathrm{~mm} / \mathrm{yr}$ and a significant increase of 15 $\mathrm{mm} / \mathrm{yr}$ in the Beaufort Sea, corresponding to changes in the Beaufort Gyre relating to wind driven phenomenon that leads to freshwater accumulation. Using individual contributors the authors were also able to assess and close the Arctic sea level trend budget over the period 2005-2015 within the error bars, for the first time. Using optimal estimation, Fu analyses statistical properties of decadal global mean sea level variability, which is of importance to understanding its longer-term evolution with climate change. He finds that the estimated standard error of the trend determined from the global mean sea level record from radar altimetry is about $0.3 \mathrm{~mm} / \mathrm{yr}$ on decadal scales, which is comparable to the widely quoted $0.4 \mathrm{~mm} / \mathrm{yr}$ systematic error and can therefore not be neglected in the error budget.

Another two contributions to this Research Topic are related to the interplay between changes in sea level and coastal morphology. Ulm et al. investigate the impact a loss of a Barrier island would have on water levels and waves along the coastline of Tampa Bay. Barrier Islands make up an eight of the world's coastlines and buffer the mainland coastal areas from storm surge and wave energy. Using a numerical model, they find that that loss of the Egmont Key Island at the entrance to Tampa Bay would result in significantly increased water level and wave heights in the Bay. Le Cozannet et al. consider the applicability of the widely-used Bruun rule in predicting shoreline retreat on sandy beaches with sea level rise. Considering probabilistic sealevel rise scenarios, they propagated these uncertainties through the sediment balance equation, that sums the Bruun effect with other drivers in an attempt to better understand where and when the Bruun rule can be (in)validated. Their results confirm that low-energy gently sloping beaches with little human impacts and small gradients in longshore drift and sheltered from storms are the most relevant to assess the validity of the Bruun rule in the sediment balance equation.

The final two contributions deal with impacts of sea level change on coastal communities. Sorensen et al. investigate couplings between sea state and flood hazard at present and in the future for the town of Thyboron in Denmark. Using a range of datasets and stakeholder interviews, their study includes a detailed analysis of change and variability in the groundwater table, precipitation, land motion, geotechnical ground properties, sewerage systems, and other infrastructure. They find that apart from obvious adverse effects from future storm surge events, knowledge about the coupled effects of the abovementioned parameters needs to be taken into account to reach optimal mitigation and adaptation measures. Wolff et al. assess sea-level rise related coastal flood impacts for Emilia-Romagna in Italy using the Dynamic Interactive Vulnerability Assessment (DIVA) modeling framework. Their results emphasize that the scale of assessment and resolution of the input data can have significant implications for the results of coastal flood impact assessments. They highlight that understanding and communicating these implications is essential for effectively supporting decision makers in developing long-term robust and flexible adaptation plans.

Overall, these papers illustrate the multi-disciplinary nature of sea level research, cross-cutting many fields of research including: oceanography, meteorology, geology, coastal morphodynamics, engineering, and the social-economic aspects. Collectively, the articles in this Research Topic represent an interesting range of perspectives and original studies that contribute to understanding the dynamic nature of sea level and its impacts across a wide range of time and space scales. Enjoy reading them!

\section{AUTHOR CONTRIBUTIONS}

IH, MM, SD, and FM co-wrote this editorial.

\section{ACKNOWLEDGMENTS}

We thank the authors of the papers included in this Research Topic for their excellent contributions. 


\section{REFERENCES}

Church, J. A., Clark, P. U., Cazenave, A., Gregory, J. M., Jevrejeva, S., Levermann, A., et al. (2013). "Sea Level Change. Climate Change 2013: The Physical Science Basis," in Contribution of Working Group I to the Fifth Assessment Report of the Intergovernmental Panel on Climate Change, eds T. F. Stocker, D. Qin, G.K. Plattner, M. Tignor, S. K. Allen, J. Boschung, A. Nauels, Y. Xia, V. Bex, and P. M. Midgley (Cambridge, UK; New York, NY: Cambridge University Press).

Hallegatte, S., Green, C., Nicholls, R. J., and Corfee-Morlot, J. (2013). Future flood losses in major coastal cities. Nat. Clim. Change 3, 802-806. doi: 10.1038/nclimate1979

IPCC (2014). “Climate Change 2014: "Synthesis Report," in Contribution of Working Groups, I, II and III to the Fifth Assessment Report of the Intergovernmental Panel on Climate Change, eds R. K. Pachauri and L. A. Meyer (Geneva: Core Writing Team; IPCC), 151.
McGranahan, G., Balk, D., and Anderson, B. (2007). The rising tide: assessing the risks of climate change and human settlements in low elevation coastal zones. Environ. Urban. Copyr. 19, 17-37. doi: 10.1177/0956247807076960

Conflict of Interest Statement: The authors declare that the research was conducted in the absence of any commercial or financial relationships that could be construed as a potential conflict of interest.

Copyright (c) 2017 Haigh, Marcos, Dangendorf and Mir Calafat. This is an openaccess article distributed under the terms of the Creative Commons Attribution License (CC BY). The use, distribution or reproduction in other forums is permitted, provided the original author(s) or licensor are credited and that the original publication in this journal is cited, in accordance with accepted academic practice. No use, distribution or reproduction is permitted which does not comply with these terms. 